\title{
Nilai-Nilai Asthabrata Sebagai Local Wisdom Untuk Penguatan Sikap Kepemimpinan Dalam Pembelajaran Sejarah Indonesia
}

\section{Siti Rhohana}

Universitas Sebelas Maret

sitirhohana@student.uns.ac.id

\section{Article History}

received $1 / 9 / 2021$

revised $1 / 10 / 2021$

accepted 1/11/2021

\begin{abstract}
This study examines efforts to inculcate Asthabrata values as local wisdom to strengthen leadership attitudes in learning. The objectives of this study are 1) to describe the Astabrata values as local wisdom 2) to describe the efforts to inculcate Asthabrata values to strengthen leadership attitudes in history learning. The methodology used in this study is a literature study. Based on the literature study, the authors found that in Asthabrata's values as Javanese local wisdom, there are eight characteristics that must be possessed by a leader. These eight attributes are based on the disposition of the Eight gods, namely Indra, Yama, Surya, Candra, Bhayu, Kuwera, Baruna and Agni. For the Javanese people, these Asthabrata values have been applied since a long time ago, especially when the kingdoms were still standing in the archipelago. Therefore, it would be better if these values are applied in the present. Attitude strengthening efforts can be integrated through Asthabrata values by utilizing historical learning. So, efforts to instill Asthabrata values as local wisdom can be used to strengthen leadership attitudes in students.
\end{abstract}

Keywords: asthabrata values, local wisdom, leadership attitude, history learning

\section{Abstrak}

Penelitian ini mengkaji upaya penanaman nilai-nilai Asthabrata sebagai local wisdom untuk penguatan sikap kepemimpinan dalam pembelajaran sejarah. Tujuan dari penelitian ini yaitu 1) Mendeskripsikan nilai-nilai Astabrata sebagai local wisdom 2) Menguraikan upaya penanaman nilai-nilai Asthabrata untuk penguatan sikap kepemimpinan dalam pembelajaran sejarah. Metodologi yang digunakan dalam kajian ini adalah studi kepustakaan. Berdasarkan studi kepustakaan tersebut, penulis menemukan dalam nilai-nilai Asthabrata sebagai local wisdomJawaterdapat delapan sifat yang harus dimiliki oleh seorang pemimpin. Delapan sifat tersebut didasarkan pada watak delapan dewa yakni Indra, Yama, Surya, Candra, Bhayu, Kuwera, Baruna dan Agni.Bagi masyarakat Jawa Nilai-nilai Asthabrata ini telah terapkan sejak dulu terutama saat kerajaan-kerajaan masih berdiri di nusantara. Oleh sebab itu, akan lebih baik apabila nilai-nilai tersebut diterapkan di masa kini. Upaya penguatan sikap kepemimpinan dapat diintegrasikan melalui nilai-nilai Asthabrata dengan memanfaatkan pembelajaran sejarah. Jadi, upaya penanaman nilai-nilai Asthabrata sebagai local wisdom dapat digunakan sebagai penguatan sikap kepemimpinan pada siswa.

Kata Kunci: nilai-nilai asthabrata, local wisdom, sikap kepemimpinan, pembelajaran sejarah

Social, Humanities, and Education Studies (SHEs): Conference Series https://jurnal.uns.ac.id/shes 


\section{PENDAHULUAN}

Minimnya kepemimpinan pada diri seorang pemimpin memicu terjadinya krisis kepemimpinan. Krisis kepemimpinan disini bukan berarti tidak adanya pemimpin dalam suatu masyarakat, melainkan kurangnya sifat-sifat kepemimpinan yang seharusnya tercermin pada diri seorang pemimpin. Terjadinya krisis kepemimpin salah satuny disebabkan oleh dimensi personal yang terdapat pada diri seorang pemimpin. Dalam konteks masyarakat Indonesia, krisis kepemimpinan dapat dilihat dari fenomena korupsi dalam birokrasi. Data yang dirilis oeh Indonesia Corruptin Watch (ICW) mencatat bahwa kerugian ngara akibat korupsi yang ditangani oleh Komisi Pemberantasan Korupsi (KPK) sebesar Rp 805 miliar pada tahun 2020. Walaupun angka ini turun namun tetap saja indeks korupsi di Indonesia masih tinggi. Terlebih lagi kasus korupsi ini dilakukan oleh aparat negara yang berprofesi sebagai anggota DPR dan DPRD, kepala Lembaga/Kementerian, Pegawai Swasta, Politikus, BUMN, Walikota/Bupati dan Wakil Bupati, Pejabat Eselon I,II,III, IV dan lain-lain dengan total tersangka sebanyak 109 orang (Laporan Tahunan KPK 2020).

Nilai-nilai kearifan lokal dirasa memilki kedudukan penting dalam membentuk kepemimpinan seorang individu. Seorang pemimpin pada dasarnya bukan hanya mementingkan mengenai kompetensi saja, namun karakter yang baik sangat diperlukan untuk membentuk kepribadian pemimpin tersebut. pemimpin juga memerlukan sifat-sifat khusus yang bersumber dari lingkungan tempat dirinya tumbuh. Indonesia memiliki nilai-nilai kepemimpinan yang tersimpan dalam warisan sejarah dan budaya masyarakat sebagai kearifan lokal. Salah satu nilai kepemimpinan yang menjadi local wisdom yaitu Asthabrata. Asthabrata merupakan suatu sistem mengenai tipe idealnya seotang pemimpin yang berkembang dalam etnis masyarakat Jawa. Asthabrata umumnya menjelaskan mengenai delapan watak dewa yang kemudian dijadikan nilai, pedoman dan patokan bagi masyarakat untuk membentuk sosok pemimpin yang ideal. Delapan nilai Asthabrata diwariskan dari zaman ke zaman melalui epos, kakawin, lakon wayang maupun serat. Sehingga nilai-nilai asthabrata dapat dijadikan sebagai budaya yang mempengaruhi aspek psikologis, wacana dan praktik sosial individu dalam ruang lingkup yang lebih luas atau yang disebut struktur masyarakat (Sarwono, 2015: 23-33).

Pada era saat ini apabila nilai-nilai Asthabrata diaktualisasikan sebagai pedoman yang ideal di masyarakat tentunya masih relevan. Kerelevanan ini dapat dibuktikan dengan adanya wacana asthabrata yang masih sering kali dijadikan sebagai bahan diskusi, terdapat dalam buku-buku kepemimpinan, opini dalam surat kabar, tema dalam suatu seminar serta perbincangan di media lainnya. Maka dengan hal itu, nilainilai asthabrata juga dapat dikembangkan dalam pembelajaran, sehingga dengan adanya pembelajaran tersebut dapat digunakan sebagai modal kepemimpinan baik untuk saat ini maupun mendatang.

Pembelajaran Sejarah Indonesia (umum) merupakan saluran yang tepat untuk upaya penanaman nilai-nilai asthabrata sebagai penguatan kepemimpinan pada tingkat SMA. Pembelajaran sejarah Indonesia memungkinkan adanya aktualisasi nilai sejarah dan budaya dalam aktivitas pembelajaran. Pembelajaran sejarah memberikan peluang bagi para peserta didik untuk mengaktualisasikan nilai dari suatu peristiwa, aktivitas dna budaya pada suatu masyarakat. Seusia dengan pernyataan Fancis Bacon, pembelajaran sejarah merupakan proses mendidikan manusia menjadi bijak. Proses menjadi bijak tersebut dapat melalui pengambilan aspek nilai dan hikmah dari suatu peristiwa yang terjadi di masa lampau (Rowse, 2008: 168). Kemudian nilai dan hikmah yang dihasilkan akan membantu manusia untuk memecahkan suatu masalah yang dihadapi pada saat ini maupun di masa yang akan datang (Gottschalk, 2008: 138). 


\section{KAJIAN TEORI}

Kearifan lokal atau local wisdom merupakan kebijakan atau nilai-nilai yang dipunyai oleh masyarakat lokal atau daerah yang diwariskan secara turun-temurun dari satu generasi ke generasi berikutnya. Nilai-nilai lokal diantaranya dapat berupa filosofi dan pandangan hidup yang terwujud dalam berbagai bidang kehidupan seperti tata nilai sosial dan ekonomi, arsitektur, kesehatan, tata lingkungan dan sebagainya (Romadi dan Kurniawan, 2017: 84). Bagi masyarakat pendukungnya, local wisdom diyakini sebagai warisan budaya, dan wajib dilestarikan sebagai wujud rasa hormat pada budaya dari para leluhurnya.

Local wisdom menghasilkan suatu keyakinan, filosofi, pandangan hidup atau nilai-nilai lokal. Dalam konsep historiografi, kearifan lokal dapat membentuk sejarah lokal, sebab kajian sejarah lokal merupakan studi tentang kehidupan masyarakat atau khususnya komunitas dari suatu lingkungan sekitar (neighborhood) tertentu dalam dinamika perkembangannya dalam berbagai aspek kehidupan (Widja dalam Mulyana, 2009:3). Lingkungan sekitar (neighborhood) merupakan batasan keruangan, dimulai dari keruangan yang terkecil misalnya keluarga hingga masyarakat setempat, lokal atau daerah.

Asthabrata merupakan bagian dari sistem informasi, ide, gagasan dan nilai mengenai idealnya tipe pemimpin dan kepemimpinan dalam masyarakat Jawa (Koentjaraningrat, 1974). Secara umum Asthabrata mendeskripsikan mengenai delapan watak dewa yang dijadikan nilai, pedoman dan patokan masyarakat Jawa untuk menentukan dan membentuk figur pemimpin yang ideal. Delapan watak dalam Asthabrata yang harus dimiliki oleh seorang jawa atau pemimpin yakni, Endra, Surya, Bayu, Kuwera, Baruna, Yama, Candra dan Brama (Moertono, 1987). Delapan nilai tersebut diwariskan dari zaman ke zaman melalui epos, kekawin, lakon wayaung mauun serat. Berdasarkan hak tersebut asthabrata dapat dikategorikan sebagai local wisdom yang mempengaruhi masyarakat Jawa dalam aspek psikologis, wacana dan praktik sosial individu maupun kelompok.

Kepemimpinan yaitu sifat, kompetensi, sikap dan keterampilan yang dimiliki oleh seorang individu. Kepemimpinan bukan hanya diukur dari tindakan ataupun dari kedudukan struktural dari seorang individu. Kepemimpinan lebih bersifat pada pemahaman dan sikap kepemimpinan yang menubuh dan terbatin dalam diri seorang individu. Kepemimpinan berkaitan dengan dasar legitimasi, sifat ideal, struktur berfikir serta kompetensi yang harus dimiliki oleh pemimpin. Kepemimpinan dipengaruhi oleh aspek bawaan dan proses sosial sehingga pemimpin dapat dikembangkan dalam diri individu. Dengan demikian, sikap kepemimpinan dapat dikembangkan melalui prosesproses sosial, salah satunya adalah memalui pendidikan dan pembelajaran.

Paradigma kepemimpinan yang dikonsepkan oleh Ki Hadjar Dewantara (dalam Sokawati, 1989) terdiri dari tiga aspek yaitu ing ngarso sung tuladha, ing madya mangun karsa, tut wui handayani (di depan menjadi teladan, ditengah menghidupkan gairah dan dibelakang memberikan pengarahan). Maka konsep kepemimpinan model Ki Hajar Dewantara dapat dijadikan rujukan dalam model kepemimpinan yang sekarang. Model kepemimpinan Ki Hajar Dewantara mewakili konsep kepemimpinan Jawa yang disebut juga dengan kepemipinan paripurna atau kepemimpinan yang menyeluruh yang mencakup seluruh aspeknya yang bersifat keteladanan dengan memberikan contoh yang baik untuk masyarakatnya.Salah satu konsep kepemimpinan Jawa adalah ajaran asthabrata.

Asthabrata yang secara etimologis berasal dari bahasa Sansekerta, Asta berarti delapan; dan Brata berarti laku atau pedoman. Ajaran asta brata pada intinya memuat delapan ajaran perilaku kepemimpinan yang disimbolisasikan dengan sifatsifat dewa alam, yaitu: langit, matahari, angin, air, samudra, bulan, bintang, dan api. Sifat-sifat dewa dalam asta brata merupakan simbolisasi dari sifat elemen alam, yang dimanifestasikan oleh masyarakat Jawa kuno menjadi sifat kepemimpinan sebagai 
hasil interaksi masyarakat Jawa dengan alam (Moh. As'ad, dkk, 2011). Masyarakat Jawa melalui ajaran asta brata diajarkan untuk meneladani sifat-sifat alam yang terkandung di dalamnya dan diaplikasikan dalam bentuk perilaku (Sariyatun, 2017)

Sejarah merupakan rekontruksi masa lalu, rekontruksi dalam sejarah tersebut yaitu apa saja yang sudah dipikirkan, dikatakan, dikerjakan, dirasakan dan dialami oleh orang. Sejarah itu juga merupakan suatu ilmu yang mempelajari peristiwa dalam kehidupan manusia pada masa lampau. Sejarah bukan sekedar melahirkan cerita dari suatu kejadian masa lampau tetapi pemahaman masa lampau yang didalamnya mengandung berbagai dinamika, mungkin berisi problematika pelajaran bagi manusia berikutnya. Sejarah itu juga sebagai cabang ilmu yang mengkaji secara sistematis keseluruhan perkembangan proses perubahan dan dinamika kehidupan masyarakat dengan segala aspek kehidupannya yang terjadi dimasa lampau (Kuntowijoyo, 1995: 18). Pembelajaran sejarah mempunyai tujuan agar siswa mampu mengembangkan kompetensi untuk berpikir secara kronologi dan memiliki pengetahuan masa lampau untuk dapat memahami dan menjelaskan proses perkembangan dan perubahan masyarakat dengan keanekaragaman sosial budaya dalam rangka menemukan jati diri bangsa, serta bisa menumbuhkan jati dirinya sebagai suatu bagian dari suatu bangsa Indonesia.

\section{METODE}

Metodologi penelitian yang digunakan dalam kajian ini ada metode literature research. Menurut Nazir (2003), studi kepustakaan adalah teknik pengumpulan data dengan mengadakan studi telaah terhadap buku-buku, literartur-literatur, catatancatatan, dan laporan-laporan yang ada hubungannya dengan masalah yang ingin dipecahkan. Selanjutnya tulisan ini memanfaatkan jurnal, bahan-bahan, dan informasi yang relevan untuk dikumpulkan dikumpulkan, dibaca dan dikaji, dicatat sebagai pedoman ataupun sumber referensi. Metode studi pustaka dalam tulisan ini dapat dijadikan sebagai data dan sumber data mengenai topik masalah. Studi pustaka ini bertujuan untuk memberikan gambaran kepada pembaca, tentang topik masalah yang sedang diteliti.

\section{Nilai-nilai Asthabrata sebagai Local Wisdom}

\section{HASIL DAN PEMBAHASAN}

Asthabrata berasal dari bahasa Sansekerta, yang di dalamnya mencakup Astha (delapan) dan Brata (perilaku atau tindakan pengendalian diri). Asthabrata melambangkan kepemimpinan ideal yang merupakan manifestasi delapan unsur alam, yaitu; bumi, matahari, api, samudra, langit, angin, bulan, dan bintang. Asthabrata sendiri berasal dari Serat Rama (Soetomo, Sujata, Astusi, 1993) yang dikisahkan sebagai wejangan Rama kepada Wibisana untuk memimpin kerajaan Ngalengka. Serat Rama merupakan gubahan dari Ramayana Kakawin yang ditulis dalam bahasa Jawa modern oleh Yasadipura I (1729-1803 M) seorang sastrawan Jawa kuno yang berasal dari Kasunanan Surakarta (Ricklefs, 1991).

Kedudukan asthabrata dalam sistem sosial masyarakat Jawa berada di ruang lingkup sistem kebudayaan. Astabrata yakni bagian dari sistem informasi, ide, gagasan dan nilai mengenai ideal type pemimpin dan kepemimpinan dalam masyarakat Jawa (Koentjaraningrat, 1974). Secara umum Asthabrata menjabarkan delapan watak dewa yang dijadikan nilai, pedoman dan patokan masyarakat Jawa untuk menentukan dan membentuk sosok ataupun figur pemimpin ideal. Delapan watak dalam asthabrata yang harus dimiliki oleh seorang raja atau pemimpin adalah Endra, Surya, Bayu, Kuwera, Baruna, Yama, Côndra, dan Brama (Moertono, 1987). Delapan watak dewa tersebut diwariskan dan direproduksi dari zaman ke zaman melalui medium epos, kakawin, lakon wayang ataupun serat. Atas dasar karakteristik tersebut, astabrata dapat dikategorikan sebagai budaya yang dapat mempengaruhi mentalitas masyarakat 
Jawa dalam ranah aspek psikologis, wacana dan praktik sosial individual ataupun kolektif. Asthabrata kemudian memiliki kedudukan sebagai suatu ajaran moral keselarasan bagi seorang kepemimpinan untuk memerintah dengan baik.

Nilai asthabrata mengandung delapan nilai yang dapat dipakai untuk dijadikan solusi dalam permasalahan. Namun, delapan nilai tersebut tidak bersifat mengikat dan mengekang. Artinya, tidak seluruh delapan nilai asthabrata harus digunakan seluruhnya. Pemimpin dapat mengambil sebagian, mengadaptasi atau memadukan nilai-nilai asthabrata dengan nilai-nilai yang lain.

Pada Kakawin Ramayana yang ditulis pada abad 9 M, Asthabrata dinarasikan dalam Caturwinsati Sarggah. Setelah kematian Rahwana, Rama memberikan nasehat kepada Wibisana untuk bangkit dan menstabilkan kondisi Alengka. Nasehat Rama tersebut disimbolkan dengan 8 dewa (asthabrata). Teks Asthabrata dalam Kakawin Ramayana beserta interpretasinya yang diterjemahkan Soewito Santoso (1981) dapat dilihat pada penjabaran dibawah ini:

Hyan Indra Yama Suryya Candranila,

Kuwera Barunagni nahan wwalu,

sira ta maka-anga san bhupati

matan sira inisti astabrata

Sifat dewa Indra ditunjukkan oleh narasi berikut ini:

Nihan brata ni san hyan Indralepen,

siranhudanaken tumreptin jagat,

sirata tuladenta Indrabrata,

sudana ya hudanta maniyabi rat.

Sifat dewa Yama ditunjukkan oleh narasi berikut ini:

Yamabrata dumanda karmmahala,

Sirekana malun malin yar pejah,

Umilwa kita malwa $n$ olah salah,

Asin umawaran sarat prih pati.

Sifat dewa Rawi ditunjukkan oleh narasi berikut ini:

Bharata Rawi manhisep wwai lana,

Ndatan kara sanaih-sanaih de nira,

Samankana kitat alap panguhen

Tatar gelisa yeka Suryyabrata.

Sifat dewa Sasi ditunjukkan oleh narasi berikut ini:

Sasibrata hamarsuka $n$ rat kabeh,

Ulahta mredu komala yan katon,

Guyunta mamanis tulyamerta,

Asin matuha panditat swagatan.

Sifat dewa Hanin ditunjukkan oleh narasi berikut ini:

Hanin ta kita yan panite ulah,

Kumawruhana buddhi nin rat kabeh,

Sucara ya panonta tatan katon,

Ya dibyaguna suksma Bayubrata..

Sifat dewa Bayu ditunjukkan oleh narasi berikut ini:

Mamuktya $n$ upabogha sambi $n$ inak,

Taman panepenen panan mwan $n$ inum 
Manandana mabhusana mahyasa,

Nahan ta Dhanada-bratanun tirun

Sifat dewa Baruna ditunjukkan oleh narasi berikut ini:

Bhrata Barunangego sanjata,

Mahawisa ya nagapasanapus,

Sirata tuladenta pasabrata,

Kitomapusana $n$ watek durjjana

Sifat dewa Agni ditunjukkan oleh narasi berikut ini:

Lanangeseni satru Bahnibrata,

Galakta ri musuhta yekapuya,

Asin sa-inasonta sirnnapasah,

Ya tekanan sinaguh Agnibrata

Delapan dari nilai asthabrata dalam Kakawin Ramayana tersebut dapat diinterpretasikan sebagai berikut:

1. Indra merepresentasikan kemurahan hati dengan mmberikan hujan kepada seluruh kerajaan

2. Yamabrata merepresentasikan dewa kematian, yang bermakna keinginan raja untuk menghukum semua unsur kejahatan dalam kerajaan.

3. Rawi mereperesentasikan kesatriaan raja. Dalam hal ini dilambangkan dewa matahari yang secara perlahan menyerap air.

4. Sasibrata merupakan dewa bulan yang membawa kegembiraan kepada dunia. Dewa bulan merepresentasikan kelembutan dan kebaikan raja kepada seluruh maskhluk di kerajaannya.

5. Hanin merupakan dewa angin yang merepresentasikan kekuatan raja untuk mnegawasi setiap gerak gerik rakyatnya dengan ketenangan dan cara yang tidak mengganggu.

6. Bayubrata merepresentasikan sikap kesederhanaan raja. Raja dilarang untuk berfoya-foya dan hanya mengejar nafsunya terhadap barang-barang yang mewah.

7. Baruna merupakan dewa yang selalu membawa senjata mematikan. Dewa Baruna merepresentasikan sikap kesiagaan raja terhadap unsur kejahatan dalam kerajaannya.

8. Agni merupakan deqa api, sebagai representasi keberanian raja dalam menghadapi musuh (Abidin, 2017)

Delapan nilai asthabrata kemudian dijadikan sebagai bagian dari kriteria sosok pemimpin yang ideal di Jawa. Pada awal abad 19, Asthabrata direproduksi kembali oleh Yasadipura I di dalam Serat Rama. Dalam Serat Rama, teks asthabrata menjadi lebih panjang. Oleh karena itu, makna dari asthabrata juga mengalami perubahan. Berikut ini merupakan interpretasi asthabrata dari Serat Rama:

1. Indra : Raja menurut watak Endra harus memiliki dana atau kekayaan yang tidak terbatas

2. Yamabrata : watak Yama mengarahkan bahwa raja harus mempu menekan semua kejahatan

3. Rawi/Surya : watak surya ditampilkan dengan kemampuan raja untuk membujuk dengan ramah dan tindakan bijaksana

4. Candra : Candra diwujudkan dalam pemimpin yang penuh kasih sayang.

5. Bayu : digambarkan sebagai watak yang teliti dan pikiran yang dalam

6. Kuwera : menggambarkan kedermawanan dalam memberikan harta benda dan hiburan 
7. Baruna : representasi kecerdasan yang tajam dan cemerlang dalam menghadapi kesulitan

8. Agni/Brama : watak keberanian yang berkobar dan tekad yang bulat dalam menghadapi musuh. (Abidin, 2017).

Berdasarkan deskripsi diatas, terdapat perbedaan narasi antara asthabrata dalam Kakawin Ramayana dan Serat Rama. Perbedaan itu terletak pada narasi asthabrata dalam Serat Rama yang lebih panjang dan berisi interpretasi Yasadipura I terhadap asthabrata. Walaupun terdapat perbedaan antara kedua narasi tersebut namun kedua narasi tersebut menggambarkan sosok idealnya seorang pemimpin dalam Jawa yang tentunya memiliki sifat yang baik.

Sedangkan Bratawijaya (1997) menerangkan 8 watak asthabrata dapat diinterpretasi sesuai dengan sifat alam semesta. Pertama menerangkan bahwa makna dari bumi adalah seorang pemimpin harus dapat bersifat sepeti bumi yang berteguh hati dan selalu mampu memberikan anugrah terhadap siapa saja yang berjasa, seperti halnya watak bumi yang kaya, suka berderma dan kaya hati. Kedua adalah air yang diinterpretasikan bahwa pemimpin mempunyai sifat tenang, bening sebagaimana karakter air, tidak tergesa-gesa dan perilakunya lemah lembut. Juga dimaknai air yang mengalir ketempat yang rendah dan selalu rendah hati dalam kehidupan sehari-hari. Ketiga sifatnya angin yang diinterpretasikan pemimpin yang bertindak cermat dan teliti serta tidak segan-segan untuk turun ke dalam masyarakat agar mengetahui persoalan yang terjadi di masyarakat sehingga pemimpin akan dapat dipercaya dan bisa dipegang perkatanya. Keempat adalah watak samudera yang mempunyai pandangan luas, merata, dan mampu menerima berbagai persoalan serta tidak boleh pilih kasih terhadap siapapun. Di samping itu seorang pemimpin harus berbesar jiwa yaitu untuk memaafkan kesalahan orang lain. Kelima merupakan watak bulan yang mempunyai maksud bahwa seorang pemimpin harus dapat menyenangkan, menarik hati dan memberi terang kepada anak buah yang dipimpinnya. Keenam adalah watak matahari yang diinterpretasikan pemimpin harus mampu memberikan motivasi, memberi spirit, memberi kehidupan dan memberikan kekuatan kepada seluruh masyarakat. Ketujuh merupakan watak api yang dapat diartikan bahwa pemimpin harus tegas dan adil tanpa pandang bulu atau pilih kasih. Kedelapan adalah watak bintang yang diartikan bahwa pemimpin harus dapat memberikan petunjuk, memberikan arahan dan bimbingan agar masyarakat mampu menyelesaikan persoalan dengan baik. Nilai-nilai asthabrata tersebut merupakan watak yang harus dimiliki dan diteladani bagi pemimpin ataupun seorang indivisu.

Ki Siswoharsojo menerangkan (dalam Susetya, 2007: 16) asthabrata adalah suatu pedoman yang seyogyanya dijadikan sebagai tugas atau kewajiban hidup yang sedemikian rupa hingga meresapi ke dalam sanubari dan diterapkan dalam kehisupan sehari-hari. Dengan kata lain, asthabrata ialah watak tiap manusia yang baik yang harus dimiliki dan dikembangkan dalam jiwa raga manusia dalam menjalani kehidupan. Sehingga dengan adanya nilai-nilai asthabrata tersebut dijawadikan masyarakat Jawa sebagai local wisdom.

\section{Pengintegrasian Nilai-nilai Asthabrata dalam Pembelajaran Sejarah}

Telah menjadi suatu kelaziman bahwa masyarakat Indonesia merupakan masyara-kat yang penuh dengan keberagaman (kebhinnekaan). Keberagaman merupakan ciri khas atau karakteristik masyarakat kita, dan telah mengakar dalam kehidupan masyarakat Indonesia. Keberagaman masyarakat Indonesia antara lain meliputi; suku bangsa, bahasa, adat-istiadat, agama dan sebagainya (Utami \& Widiadi, 2016: 106). Setiap masyarakat lokal, setempat, atau daerah memiliki kebudayaan lokal, seperti; cerita rakyat, tradisi lisan, foklor, keyakinan, kesenian tradisional, makanan tradisional, upacara tradisional, permainan tradisional, gotong royong dan sebagainya. Kebudayaan lokal tersebut men-jadi sumber nilai-nilai lokal atau local 
wisdom.Sebagai upaya untuk melestarikan local wisdom, guru sejarah sebaiknya menginventarisasi dan menggali kearifan lokal di daerahnya, dan menanamkan/ mengintegrasikan kearifan lokal atau local wisdom tersebut dalam pembelajaran sejarah.

Penanaman nilai-nilai local wisdom dalam pembelajaran sejarah pada kurikulum 2013 mempunyai "tempat yang layak". Hal ini dapat dilihat sebagaimana kompetensi yang aan dicapai dalam pembelajaran tidak hanya untuk meningkatkan kompetensi pengetahuan (KI-3) dan Ketrampilan (KI-4), namun juga bertujuan untuk mencapai kompetensi sikap seperti halnya kearifan lokal yang terdapat pada Kompetensi Inti 2 (KI-2) yaitu sikap sosial atau pembentukan karakter. Sehingga nilai-nilai, karakter sikap, etika, norma dan semacamnya dalam kearifan lokal dapat direpresentasikan dalam pembelajaran sejarah. Maka secara umum penanaman sikap local wisdom dalam kurikulum 2013 dapat dilakukan dengan dua cara yakni; pertama melalui keteladanan, pembiasaan, dan budaya sekolah dan yang kedua melalui nilai-nilai sebagai dampak/efek pengiring dalam pembelajaran ata nilai yang diperoleh scara tidak langsung dalam pembelajaran pada KD pengetahuan dan ketrampilan (Dit. PSMA, 2017: 5).

Pendidikan berbasis local wisdom merupakan pendidikan yang mengajarkan peserta didik untuk selalu dekat dengan situasi konkret yang mereka hadapi. Hal ini selaras dengan pendapat Suwito dalam Wagiran (2012) yang mengemukakan pilar pendidikan local wisdom meliputi 1) membangun manusia berpendidikan harus berdasarkan pada pengakuan eksistensi manusia sejak dalam kandungan; 2) pendidikan harus berbasis kebenaran dan keluhuran budi, menjauhkan dari cara berpikir tidak benar dan grusa-grusu atau waton sulaya; 3) pendidikan harus mengembangkan ranah moral, spiritual (ranah efektif) bukan sekedar kognitif dan ranah psikomotorik; dan 4) sinergitas budaya, pendidikan dan pariwisata perlu dikembangkan secara sinergis dalam pendidikan yang berkarakter. Pendidikan berbasis kearifan lokal dapat digunakan sebagai media untuk melestarikan potensi masing-masing daerah. Kearifan lokal harus dikembangakan dari potensi daerah (Wagiran, 2012:333-334).

Nilai-nilai Asthabrata sebagai local wisdom pada masyarakat jawa dapat direlevansikan dalam materi pada pembelajaran Sejarah Indonesia (Umum). Nilai-nilai Asthabrata tersebut dapat dintegrasikan untuk memperkaya materipembelajaran pada KD 3.6 dan KD. 4.6 mapel Sejarah Indonesia (Umum) kelas X. Adapun bunyi dari KD 3.6 yaitu "menganalisis perkembangan masyarakat, pemerintahan, dan budaya pada masa kerajaan-kerajaan Hindu dan Buddha di Indonesia serta menunjukkan bukti-bukti yang masih berlaku pada kehidupa masyarakat Indonesia masa kini". Sedangkan KD 4.6 berbunyi "menyajikan hasil penalaran dalam bentuk tulisan tentang nilai-nilai dan unsur budaya yang berkembang pada masa kerajaan Hindu dan Buddha yang masih berkelanjutan dalam kehidupan bangsa Indonesia pada masa kini" (Lampiran Permendikbud No. 37 Tahun 2018).

Pengintegrasian nilai-nilai local wisdom seperti halnya nilai-nilai Asthabrata tentu saja memiliki nilai-nilai atau makna yang terkandung di dalamnya. Guna memperoleh nilai-nilai atau makna yang maksimal maka pembelajaran harus dilaksanakan secara efektif. melalui pembelajaran efektif, tentunya akan mendorong peserta didik tidak hanya mampu memahami materi yang dipelajari, tetapi juga mendorong berfikir logis, kritis dan kreatif, serta keterampilan historis, yang pada gilirannya peserta didik memiliki kemampuan dalam menangkap nilai-nilai atau makna yang terkandung da-lam materi pembelajaran. Hal ini menunjukkan bahwa pembelajaran sejarah bermuatan nilai, berarti dalam pembelajaran tersebut tetap mengindahkan aspek pengetahuan dan keterampilan. Dalam kaitannya dengan kemampuan untuk memaknai sejarah, Ankersmit menyatakan bahwa pemaknaan sejarah berkaitan dengan penafsiran tentang pertanyaan mengenai tujuan dan gunanya pengkajian sejarah (1987: 369). 
Upaya penanaman local wisdom (kearifan lokal) yang terintegrasi dalam pembelajaran sejarah dapat dilakukan dengan dua cara yakni; (1) menerapkan model pembelajaran yang bersumber pada konsep pembelajaran konstruktivistik, dan (2) kemampuan untuk memaknai (mencapai nilai-nilai) dari materi pembelajaran. Penerapan tersebut diharapkan mampu mendorong peserta didik untuk membangun pengetahuannya, melalui proses mencari, menemukan, mengolah, mengkonstruksi, dan menggunakan pengetahuan dalam kehidupannya. Hal ini diasumsikan akan memiliki dampak lebih bagi siswa daripada pembelajaran yang disampaikan dengan ceramah.

\section{SIMPULAN}

Local wisdom merupakan nilai-nilai lokal antara lain meliputi keyakinan, normanorma, sikap, karakter, pengetahuan, filosofi yang diwariskan dari generasi ke generasi berikutnya. Kearifan lokal atau local wisdom ini bagi masyarakat pendukungnya diyakini sebagai suatu kebenaran dan dilestarikan sebagai wujud kepemilikan budaya dan bentuk penghorma-tan kepada budaya para leluhurnya. Salah satu local wisdom yang berkembang pada etnis masyrakat Jawa ialah nilai-nilai asthabrata. Asthabrata merupakan bagian dari sistem informasi, ide, gagasan dan nilai mengenai idealnya tipe pemimpin dan kepemimpinan dalam masyarakat Jawa Asthabrata umumnya menjelaskan mengenai delapan watak dewa yang kemudian dijadikan nilai, pedoman dan patokan bagi masyarakat untuk membentuk sosok pemimpin yang ideal.

Delapan watak dalam Asthabrata yang harus dimiliki oleh seorang jawa atau pemimpin yakni, Endra, Surya, Bayu, Kuwera, Baruna, Yama, Candra dan Brama. Nilai-nilai asthabrata dapat dijadikan sebagai budaya yang mempengaruhi aspek psikologis, wacana dan praktik sosial individu dalam ruang lingkup yang lebih luas atau yang disebut struktur masyarakat. Penanaman nilai-nilai local wisdom dalam pembelajaran sejarah pada kurikulum 2013 mempunyai "tempat yang layak". Hal ini dapat dilihat sebagaimana kompetensi yang aan dicapai dalam pembelajaran tidak hanya untuk meningkatkan kompetensi pengetahuan (KI-3) dan Ketrampilan (KI-4), namun juga bertujuan untuk mencapai kompetensi sikap seperti halnya kearifan lokal yang terdapat pada Kompetensi Inti 2 (KI-2) yaitu sikap sosial atau pembentukan karakter kepemimpinan pada siswa. Sehingga dengan adanya nilai-nilai asthabrata maka dapat dijadikan sebagai penguatan sikap kepemimpiinan pada siswa SMA dengan melalui pembelajaran sejarah sebagai wadahnya. Dengan menanamkan konsep nilai-nilai asthabrata maka akan memperkuat sikap kepemimpinan generasi muda dan siap bersaing dalam globalisasi.

\section{DAFTAR PUSTAKA}

Abidin, Nur Fatah. (2017). "Model Pembelajaran Sejarah Indonesia Baru Berbasis Nilai Asthabrata dengan Pendekatan Dekonstruksi untuk Meningkatkan Sikap Kepemimpinan Mahasiswa Prodi Pendidikan Sejarah FKIP Universitas Sebelas Maret Surakarta." PhD diss., UNS (Sebelas Maret University),

Ankersmit, F.R. (1987). Refleksi Tentang Sejarah, Pendapat-pendapat Modern Tentang Filsafat Sejarah. Jakarta: PT Gramedia. Dit. PSMA. 2017. Panduan Penilaian Oleh Pendidik dan Satuan Pendidikan Sekolah Menengah Atas. Jakarta; Kemendikbud.

Gottschalk, L. (2008). Mengerti Sejarah. Jakarta: Penerbit Universitas Indonesia.

Koentjaraningrat. (1974). Kebudayaan Mentalitas dan Pembangunan. Gramedia Pustaka Utama, Jakarta.

Kuntowijoyo. (1995). Pengantar IImu Sejarah. Yogyakarta: Bentang Budaya.

Lampiran Permendikbud RI Nomor 37 Tahun (2018). Tentang Perubahan Atas Permendik-bud RI Nomor 24 Tahun 2016 Tentang Kompetensi Inti dan Kompetensi Dasar Pelajaran Pada Kurikulum 2013 Pada Pendidikan Dasar dan Menengah. 
Mahmud, Djulia Indriani AH. (2011). "Learning of Tanggomo Local History To Improve Students' Critical Thinking Skills." HISTORIKA 23, no. 1: 57-60.

Mulyana, A. (2009). Mengembangkan Kearifan Lokal Dalam Pembelajaran Sejarah, Makalah yang disajikan pada Seminar Internasional "Mengembangkan Social Skill Dalam Pembelajaran IPS di Sekolah" Kerjasama Jurusan Pendidikan Sejarah FPIPS UPI dengan Universitas Kebangsaan Malaysia, Bandung, 29 Januari 2019.

Nazir, Mohamad. (2003). Metode Penelitian. Jakarta : Ghalia Indonesia.

Ricklefs, M. (1991). Sejarah Indonesia Modern (terj.). Yogyakarta: Gadjah Mada University Press.

Romadi dan Kurniawan, F. (2017). Pembelajaran Sejarah Lokal Berbasis Folklore Untuk Menanamkan Nilai Kearifan Lokal Kepada Siswa. Jurnal Sejarah dan Budaya.Vol XI No 1.

Rowse, A.L. (2014). Apa Guna Sejarah?. Depok: Komunitas Bambu.

Sariyatun, Sariyatun. (2017) "Reaktualisasi Ajaran Kepemimpinan dalam Serat Wedhatama." In Prosiding Seminar Nasional Teknologi Pendidikan.

Setiyowati, Ninik. (2015). "Asta Brata: Pemetaan Kompetensi Kepemimpinan Jawa Untuk Meningkatkan Organizational Wellness Pada Institusi Pendidikan Di Jawa Timur." H. Ek. Erawan, Erlyn; Sumargi, Agnes Maria; Effendy, Nurlaila: 173-183.

Soetomo, Sujata, P. Astusi, S. (1993). Serat Rama. Semarang: Yayasan Studi Bahasa Jawa.

Susetya. W. (2007). Kepemimpinan Jawa. Yogyakarta : Narasi

Tim Penyusun Laporan KPK. 2020. Laporan Tahunan KPK 2020. Jakarta: Komisi Pemberantasan Korupsi.

Utami, I.W.P. \& Widiadi, A.N. 2016. Wacana Bhineka Tunggal Ika Dalam Buku Tek Sejarah. Jurnal Paramita Vol. 26 No. (1).

Wagiran. (2012). Pengembangan Karakter Berbasis Kearifan Lokal Hamemayu Hayuning Buwana (Identifikasi Nilai- nilai Karakter Berbasis Budaya). Jurnal Pendidikan Karakter No (3)

Witasari, Nina. (2016). "Astha Brata dan Pranata Mangsa: Alam dan Relasi Kuasa dalam Konteks Agraria di Jawa." Paramita: Historical Studies Journal 25, no. (2), 225-237.

Zakub, Riky. (2015). "Pitutur Luhur dan Konsep Hasta Brata dalam Antopologi Geguritan Blendheg Segara Kidul Karya Turiyo Ragilputra dan Relevansinya Sebagai Materi Ajar Pembelajaran 